\title{
Hvor ofte blir artikkelen sitert?
}

\author{
«Impact factor» er et gjennomsnittsmål for hvor hyppig artikler \\ blir sitert i løpet av et bestemt tidsrom. På norsk er skrivemåten \\ impaktfaktor.
}

Begrepet «impaktfaktor» er knyttet til amerikaneren Eugene Garfield (f. 1925) som lanserte ideen om denne type siteringsanalyse i en artikkel i Science i 1955 (1). Impaktfaktor beregnes som antall siteringer av artikler i et tidsskrift i løpet av en toårsperiode dividert på antall artikler som det samme tidsskriftet publiserte i perioden. Av de generelle medisinske tidsskriftene ligger New England Journal of Medicine på topp med en impaktfaktor på 52,589 i 2007. Det innebærer at hver artikkel siteres i gjennomsnitt omtrent 53 ganger. Det er viktig å merke seg at dette er et gjennomsnittsmål, dvs. at noen artikler blir sitert langt oftere, mens andre artikler kanskje ikke blir sitert i det hele tatt.

Interessen for en slik publiseringsindikator har økt sterkt i de senere årene (2). Produksjonen av impaktfaktorer er blitt en storindustri for firmaet Thomson Reuters $(3,4)$. Selv om impaktfaktor strengt tatt kun er et mål for siteringshyppighet, brukes det i økende grad som kvalitetsmål både for enkeltartikler, tidsskrifter, forskere og forskningsinstitusjoner. Bruk og misbruk av impaktfaktor er blitt et stort tema $(3,5-7)$. En av de første som påviste svakhetene ved metoden, var den norske forskeren Per O. Seglen (7).

\section{Impaktfaktor på norsk}

I Tidsskriftet ble den norske skrivemåten impaktfaktor lansert i januar 2006 (8) og er hittil brukt ni ganger (23.12. 2008). Tidligere skrev man «impact factor» i anførselstegn eller brukte omskrivninger som tidsskriftenes prestisje, siteringshyppighet, siteringsfrekvens etc. Med den økende interessen for begrepet økte også behovet for en norsk term.

På engelsk består begrepet av to ord: impact og factor. «Impact» har en rekke betydninger, men det mest nærliggende i denne sammenhengen er innflytelse, innvirkning, effekt eller inntrykk. Det er snakk om artiklers eller tidsskrifters innflytelse. «Factor» er enklere, der har vi allerede direkteoversettelsen faktor. Man kunne tenke seg diverse sammensetninger på norsk: innflytelsesfaktor, effektfaktor osv, men disse skiller seg mye fra det opprinnelige uttrykket. For å få gjennomslag for en norsk skrivemåte ble det lagt vekt på gjenkjennelighet, og man valgte en fornorsket skrivemåte også av det første ordet. I samsvar med praksis på norsk skrives ordet i ett og uten bindestrek.

Impaktfaktor kan uttales, skrives og bøyes etter regler for norsk språkbruk. Et enkelt nettsøk gir nå 41 treff (23.12. 2008). Brukerne og tiden vil avgjøre slitestyrken til ordet impaktfaktor

\section{Erlend Hem}

erlend.hem@medisin.uio.no

Raida ødegaard

Tidsskriftet

\section{Litteratur}

1. Garfield E. The history and meaning of the journal impact factor. JAMA 2006; 295: 90-3. http:// jama.ama-assn.org/cgi/content/full/295/1/90 (23.12.2008)

2. Smith R. Commentary: the power of the unrelenting impact factor - is it a force for good or harm? Int J Epidemiol 2006; 35: 1129-30.

3. Haug C. Profittkarusellen. Tidsskr Nor Lægeforen 2007; 127: 1173

4. Thomson Reuters. Journal selection process. http://scientific.thomsonreuters.com/mjl/selection (23.12.2008).

5. Saugstad OD. Klinisk medisinsk forskning - fra galt til verre? Tidsskr Nor Lægeforen 2003; 123: 142

6. Haug C. På kjempenes skuldrer. Tidsskr Nor Lægeforen 2006; 126: 583

7. Seglen PO. Why the impact factor of journals should not be used for evaluating research. BMJ 1997; 314: 498-502. www.bmj.com/cgi/content/ full/314/7079/497 (23.12.2008).

8. Nylenna M. Små nasjonale tidsskrifter - har de noen fremtid? Tidsskr Nor Lægeforen 2006; 126 4-8. 